\title{
Human Rights and States Paradoxes
}

\author{
Insan Haklart ve Devletlerin Paradoksları
}

Mehmet Emin ERENDOR

Dr., Çukurova Üniversitesi, (mehmeterendor@gmail.com)

\section{Keywords:}

Human Rights

Universal

Declaration of

Human Rights

International

Covenant on Civil

and Political Rights

Paradoxes

Capital Punishment

\begin{abstract}
The concept of human rights has been issued since the seventeenth century in the international community. Human rights during the seventeenth and eighteenth centuries were evaluated under the sovereignty. Abuse of human rights are the main problem in the states, although the states are responsible to protect any individual who lives in its territory. Although states have responsibility to protect their citizens or other people from any threat or human rights abuses, states are the main violator of the human rights. There is a dilemma in the human rights in terms of states responsibility and its role. Therefore, the main aim of this article is to identify and examine the human rights and states paradoxes.
\end{abstract}

\author{
Anahtar kelimeler: \\ Insan Haklarl \\ Insan Haklart \\ Evrensel \\ Beyannamesi \\ Uluslararast \\ Medeni ve Siyasal \\ Haklar Sözleșmesi \\ Çelişkiler \\ Idam Cezast
}

\begin{abstract}
ÖZET
Insan Hakları kavramı 17. yüzyıldan bu yana uluslararası toplumun konularından birisidir. 17. ve 18. yüzyıllar sırasında insan hakları devletin egemenlik hakları altında değerlendirilmekteydi. Devletler kendi toprakları içerisinde yaşayan her bireyi korumakla yükümlü ve sorumlu olmasına rağmen, insan hakları ihlalleri devletlerin ana problemlerinden birisi olarak ortaya çıkmaktadır. Ayrıca, devletler kendi vatandaşlarını ve ülke sınırları içerisindeki diğer insanları korumakla sorumlu olmasına rağmen, devletler insan haklarını ihlal eden en temel kurumdur. Bunun nedeni ise devletin insan haklarl üzerindeki sorumluluğu ve rolü üzerindeki ikilemden kaynaklanmaktadır. Bu makalenin temel amacı insan haklarını ve devletlerin paradokslarını tanımlayarak bunları sorgulamaktır.
\end{abstract}

\section{INTRODUCTION}

The concept of human rights has been issued since the seventeenth century. According to the doctrine of the sovereignty, modern states defend their own citizens by evaluating the external dangers. During the seventeenth century, sovereignty was the most important concept for the international system. In the seventeenth century, the natural rights have been approached at the international level, and after the Reform Movements of the eighteenth and nineteenth centuries, states began to give new rights to its citizens with human rights acts, but these rights had some limitations. For example, these rights were given only to Men like the Declaration of the Rights of Man and of the Citizen (Declaration of the Rights of Man and of the Citizen) in France and the Virginia Declaration of Rights (The Virginia Declaration of Rights ) in America.

After these centuries, scholars had examined and analysed some topics related to human rights, but a comprehensive agreement or act could not be established until 1945 the United Nations. In 1948, the Universal Declaration of Human 
Rights was adopted by the United Nations General Assembly (Trindade, 2008). According the Declaration, all states have to protect and promote human rights on its own territories, but these rights sometimes can transform into a paradox. Steiner argued that "Human rights violations occur within a state, rather than on the high seas or in outer space outside the jurisdiction of any one state" (Steiner et.al., 2008, p. 987).

Although, the human rights have the development in the international area, still it has been assigned from states.

The main aim of this study is to analyse state responsibilities for promoting and protecting human rights and then sampling state's paradoxes. This study is divided into three main parts. The first part is about the historical background of human rights, and the second part includes information about the UN Charter and other Human Rights Acts in terms of how states the promote and protect human rights in their territory, and if they have any specific institution, what they are and finally, what are the states paradoxes in the human rights.

\section{HISTORICAL DEVELOPMENT OF HUMAN RIGHTS}

In the seventeenth and eighteenth centuries, the concept of human rights was one of the most important issues in the world, because during these periods, there were pivotal human rights movements. The scholars and the philosophers of these periods described the concept of human rights as natural rights or nature of man. Although human rights have been a matter between the state and its people, states protected their own citizens from external dangers under the doctrine of sovereignty, because sovereignty was one of the most important issue in the international system (Lyons and Mayall, 2003, p. 6).

Parallel to the development of the concept of natural rights which are based on in certain inalienable rights, John Locke, who was accepted father of Liberalism, mentioned that these rights as the rights to live, liberty and property. Therefore, these rights are inalienable and inseparable (Shaw, 2008, p. 266). Besides, these rights have to be established upon a social contract. The state sovereignty was one of the most important issues in this period, because the states protected their own citizens from external dangers and interference.

In the nineteenth century, the state sovereignty and jurisdiction was the highest point, but these concepts accepted a right of humanitarian intervention in this period by international community (Shaw, 2008, p. 270). Although the states accepted human rights as natural rights of people, the international community did not have any specific institutions to judge criminals and states that violate human rights to protect innocent people. After the First World War, the international community did not want to relive the same problem and the League of Nations was established in 1920 (Vermeulen, 2014 , p. 33). The establishment of the League of Nations was very important, because during the establishment of the organization a peace agreement signed between Eastern European and Balkan States which was related to states and minority rights. According to this agreement, the contracting states committed to protecting minorities and creating equality of opportunity in their own territories (Shaw, 2008, p. 271). Together with the League of Nations, first mechanism of international inspection was established. Since then, international human rights have begun to evolve, but the emergence of the Second World War has caused a system and this first attempt to establish an international inspection ended with a failure. Shaw argues that "the responsibility of states to prevent human rights abuses is beginning to be seriously considered while more generally the obligation upon states and for example, international organizations positively to protect human rights is becoming part of the agenda of international human rights law (Shaw, 2008, p. 276). During this period, issues of torture and genocide have been effective. With the establishment of the United Nations, human rights issues were signified and formally declared under the 1948 Universal Declaration (Goodhart, 2009, p. 15).

From 1950s onwards, human rights issue started to be handled in a more comprehensive way opening a new era for international protection of human rights.

As a consequence, until 1945 human rights studies were limited by states because of the political disputes and ineffective of the international organizations, particularly the League of Nations. But after the establishment of the United Nations and human rights violations during the World War the view of the human rights by international community has been changed and states have focused on the ideas of protecting and promoting of human rights. The next section will give more information about states responsibility for human rights and new term with respect it. 


\section{NEW TERM FOR HUMAN RIGHTS and STATES RESPONSIBILITY}

The adoption of the Universal Declaration of Human Rights has been getting increasingly interested in individualism. Donnelly mentions that, "the Universal Declaration presents itself as a common standard of achievement for all peoples and nations and states that represent them" (Donnelly, 2003, p. 34). Together with international organizations, governments started to create a significant impact on human rights abuses.

With this declaration, states were started to be understood as the main source of human rights principles. Tunkin explains the principles of respect for human rights in a different three ways, and Shaw emphasizes these principles as;

“1) All states have a duty to respect the fundamental rights and freedom of all persons within their territories; 2) states have a duty not to permit discrimination by reason of $\quad$ sex, race, religion or language, and 3) states have a duty to promote universal respect for human rights and to co-operate with each other to achieve this objective." (Shaw, 2008, p. 268).

In addition to Tunkin's principles, the state had become one of the major focal points. Therefore, Steiner argued that, "effective protection must come from within the state" (Steiner et.al. 2008, p. 1123). Each state has the authority and responsibility to protect and promote human rights its own territory, but as Shaw emphasised, "conventions on human rights do not grant rights directly to individuals" (Shaw, 2008, p. 268). All these arguments show that these rights may vary from state to state or region to the region because of state or region governmental structure. Moreover, according to the Human Rights Defenders, states are required to protect, respect and promote human rights (Human Rights Defenders: Protecting the right to Defend Human Rights, 2004, p. 17). These human right defenders work at the local or national level in their own countries as a protector and promoter of human rights, and also states support these institutions in its own territory.

Nowadays, many states have ratified at least one treaty including legal obligations to protect and to promote human rights; hence, contributed for the gradual development of protecting of human rights (Evans, 2010, p. 290). These legal obligations include social, political, economic, and cultural rights. Many states and local jurisdictions have human rights statutes, and so, the citizens or persons can be claimed their fundamental rights in their national legal system (Goodhart, 2009, p. 11). States that are party to these agreements are restricted in their own sovereignty. They have an important role to protect and improve human rights. However, on the other hand, states that signing these agreements do not mean that these rights will be protected effectively. For the realization of effective protections, some several norms and mechanisms are required. According to Reif, these mechanisms and norms are; "state adherence to human rights treaties; implementation of international human rights obligations in domestic law; a domestic legal system that provides comprehensive substantive and procedural human rights laws; effective and accessible state institutions where individuals can obtain redress for human rights breaches, such as independent courts and national human rights institutions; a lively human rights NGO community; and a population that has developed a strong human rights culture.”(Reif, 2000, p. 3). Several international organisations including the United Nations have encouraged the establishment of these institutions in the national legal systems. Thus, over the last two or three decades, the emergence of national human rights institutions have been established and improved. International rules or norms are examined by these institutions and states try to adapt them into their domestic law. Accordingly, most of the states have turned to democratic forms of governance or have attempted to improve their democratic structure. The European Union gives a progress report to the candidate countries by which they are encouraged to be more sensitive to the human rights issues. Therefore, the development of human rights institutions and protection of human rights is becoming more important for these states. Steiner mentioned that these institutions are foundations which "include governmental bodies such as national human rights commissions and human rights ombudsmen. These institutions are generally tasked with addressing a range of human rights issues" (Steiner et.al. 2000, p.1123). They aim, to firstly, fill the gap between government and civil society and secondly, to accelerate the implementation of international norms in the domestic law. Although these institutions have been established by the states and they do not have any power in decision making process, but they still have an important role in protection of human rights. In this regard, the state creates a paradox in these institutions. The final section of this paper will be analysing this paradox. 
To summarize, all states must protect, promote and respect all human rights in their country and therefore, they must implement international norms or rules in their domestic legal systems. As it mentioned in this section, the Universal Declaration of Human Rights and as well as national human rights institutions which were established by states, contribute to encourage states focus on protecting human rights issues. Although, the states must protect the human rights, it can be said that the states are still main perpetrator of the violations of their own citizen's individual rights.

\section{STATE PARADOXES}

Although the states accept and implement international human rights norms to their domestic legal system, this sometimes can create a paradox, because of the state sovereignty. Since the foundation of modern states, they have never been willing to give up their own sovereignties or powers to international organizations or a top power. For the states, sovereignty and power are indivisible and these two facts which do not share with other states or institutions, and so, it has turned into paradox. As it is mentioned above, when the state establishes a new national human rights institution to protect and promote human rights in its own country, governments do not give a power to these institutions to make binding decisions. This is a reflection of states dependence the principle of sovereignty. Also, state is still the main perpetrator the violation human rights of its citizens. Armies and police forces which were established by the states, generally act violating main principles of human rights (Goldewijk and Fortman, 1999, p. 3). Such institutions generally have unfair arrests, custody, illegal review or search, murdering, extreme violence, seizure and so on. The rights of people are limited by these institutions in any country. States often do not pay attention and in fact condone it. Most of the time, states violate international agreements. Because they want to solve their own internal problems without foreign intervention and this, leads to a difference between domestic and international laws. The main idea of the governments might be that, if international organizations or other states make any intervention in its own territories, their sovereignty will be violated, therefore, they violate human rights agreements.

Another important issue is also related to minorities. In the international level, many states have a multicultural structure. Until 1945, international community had not emphasized issues related to minorities, because minorities were accepted as a part of the majority in the state. As Lyons et.al mentioned that, "both liberal philosophy and international practice directed at human rights have historically been ill disposed to the minority problems that very often arise in situations of ethno cultural pluralism" (Lyons and Mayall, 2003, p. 50). After 1945, new system was created and after that minority rights started to develop in the international level.

According to the Article 27 of the Internal Covenant on Civil and Political Rights 1966 which was adopted by General Assembly of United Nations, if state or states which have ethnic, religious or linguistic minorities, persons belonging to this minority and with their own group members using their own cultural rights, to fulfil their religious observances and have the right to use their own language and any state do not obstruct it (International Covenant on Civil and Political Rights). Even if, such agreements have guaranteed the rights of minorities in the international area, most of the states do not accept the existence of minorities within their own state. Because if they accept a community as a minority, they need to give some rights which is manipulated by the majority members conflicting with the general principles of equality.

Besides, generally all fundamental rights are guaranteed under the international agreements and so, if states ratify them, then they have to implement, protect and promote these rights in their countries. But sometimes due to their roles, they do not implement these rights. For example, Turkey had a capital punishment until 2004 and the USA is still using capital punishment. States implement that, and they get most important fundamental rights from people. This can be big paradox for states. Additionally, headscarf is one of the most important problems for Turkey. Generally, if women wear headscarf, they cannot work at school or governmental sectors. Therefore, they cannot use their fundamental rights freely in some places.

To sum up, state is the most important violator of human rights in the world because it has more power for above everything. When they establish such institutions in the country, they do not give them any power because of they do not want to share its power with others. This situation creates a dilemma with responsibility and role. Such institutions violate human rights in the state. For example, the security forces are the most obvious feature in terms of violence and torture. 


\section{CONCLUSION}

Throughout history, state sovereignty was above all other things. The concept of human rights had always been under the sovereignty of state, and it was only perceived to protect its own citizens from external threats. Along with the development of the modern state, the concept of human rights has been considered as a broader. Because this term, the eighteenth and nineteenth centuries, in the international area, had some human rights movements. In spite of states are guaranteed human rights by international treaties or international organizations, their sovereignty have always been their first priority. Until 1945, human rights issues were not so significant at national and international level. But the Second World War changed the state perception of human rights in the world mainly, because of genocide, mass killings and holocaust. After 1945, along with the Universal Declaration of Human Rights, fundamental human rights were guaranteed under the agreements.

Furthermore, when we look at the human rights movements throughout history, we see violence, death and suffering, because, all the time states are the main perpetrator in violation of its citizens' individual rights and fundamental rights. In the international area, the state sign international agreements and it is an entity to meet these obligations. Also, nongovernmental organizations (NGOs) and intergovernmental organizations (IGOs) strive to protect human rights. Although many entities, such as IGOs and NGOs, play a role protecting and promoting human rights, still the most important entity is the state for protecting and promoting, because of its power.

As a result, both protecting and violating roles are a paradoxical for states. Therefore, good governance may be changing this situation in the future just as a protecting role.

\section{REFERENCES}

Declaration of the Rights of Man and of the Citizen, Available at: http://www.hrcr.org/docs/frenchdec.html (Accessed at: 06/10/2016)

DONNELLY, J. (2003). Universal Human Rights in Theory and Practice. New York: Cornell University Press

EVANS, M. (2010). International Law. Oxford: Oxford University Press

GOLDEWIJK, B. K. and FORTMAN, B. (1999). Where Needs Meet Rights. Geneva: WCC Publications.

GOODHART, M. (2009). Human Rights Politics and Practice. Oxford: Oxford University Press

Human Rights Defenders: Protecting the right to Defend Human Rights (2004). Available at: http://www.ohchr.org/Documents/Publications/FactSheet29en.pdf (Accessed at: 08/10/2016)

International Covenant on Civil and Political Rights. Available at: http://www2.ohchr.org/english/law/ccpr.htm\#part2 (Accessed at: 10/10/2016)

LYONS, G. and MAYALL, J. (eds.) (2003). International Human Rights in the 21st Century. Oxford: Rowman \& Littlefield Publishers

REIF, L.C. (2000). "Building Democratic Institutions: The Role of National Human Rights in Good Governance and Human Rights Protection". Harvard Human Rights Journal. Volume 13. Available at:

http://heinonline.org/HOL/Page?handle=hein.journals/hhrj13\&div=5\&g_sent=1\&colle ction=journals (Accessed at: 10/10/2016)

SHAW, M. (2008). International Law. Cambridge: Cambridge University Press

STEINER, H. J., ALSTON, P. and GOODMAN, R. (2007) 3rd ed. International Human Rights in Context. Oxford: Oxford University Press

The Virginia Declaration of Rights. Available at: http://www.usconstitution.net/vdeclar.html (Accessed at: 11/10/2016)

TRINDADE, A. (2008). Universal Declaration of Human Rights. Available at: http://untreaty.un.org/cod/avl/pdf/ha/udhr/udhr_e.pdf (Accessed at:10/10/2016)

VERMEULEN, J. (2014). Were Woodrow Wilson and Franklin D. Roosevelt the True Architects of the United Nations?. Available at: http://lib.ugent.be/fulltxt/RUG01/002/213/163/RUG01002213163_2015_0001_AC.pdf 